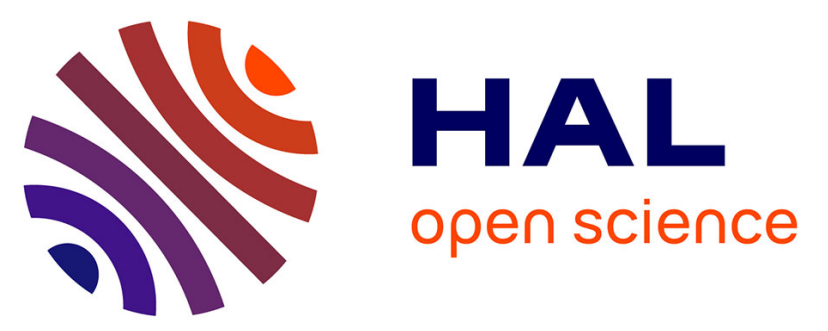

\title{
Death ligand TRAIL, secreted by CD1a+ and CD14+ cells in blister fluids, is involved in killing keratinocytes in toxic epidermal necrolysis.
}

Elisabeth de Araujo, Valérie Dessirier, Geneviève Laprée, Laurence

Valeyrie-Allanore, Nicolas Ortonne, Efstathios N. Stathopoulos, Martine

Bagot, Armand Bensussan, Maja Mockenhaupt, Jean-Claude Roujeau, et al.

\section{To cite this version:}

Elisabeth de Araujo, Valérie Dessirier, Geneviève Laprée, Laurence Valeyrie-Allanore, Nicolas Ortonne, et al.. Death ligand TRAIL, secreted by CD1a+ and CD14+ cells in blister fluids, is involved in killing keratinocytes in toxic epidermal necrolysis.: TRAIL in toxic epidermal necrolysis. Experimental Dermatology, 2011, 20 (2), pp.107-12. 10.1111/j.1600-0625.2010.01176.x . inserm-00576104

\section{HAL Id: inserm-00576104 https://www.hal.inserm.fr/inserm-00576104}

Submitted on 12 Mar 2012

HAL is a multi-disciplinary open access archive for the deposit and dissemination of scientific research documents, whether they are published or not. The documents may come from teaching and research institutions in France or abroad, or from public or private research centers.
L'archive ouverte pluridisciplinaire HAL, est destinée au dépôt et à la diffusion de documents scientifiques de niveau recherche, publiés ou non, émanant des établissements d'enseignement et de recherche français ou étrangers, des laboratoires publics ou privés. 


\section{Experimental Dermatology}

Death ligand TRAIL, secreted by CD1a+ and CD14+ cells in blister fluids, is involved in killing keratinocytes in toxic epidermal necrolysis

\begin{tabular}{|r|l|}
\hline Journal: & Experimental Dermatology \\
\hline Manuscript ID: & Draft \\
\hline Manuscript Type: & Regular Article \\
\hline Author: & nom \\
\hline Complete List of Authors: & $\begin{array}{l}\text { Tsapis, Andreas; INSERM, U976 } \\
\text { Dessirier, Valérie; INSERM, U976 } \\
\text { De Araujo, Elisabeth; INSERM, U976 } \\
\text { Lapré, Geneviève; INSERM, U976 } \\
\text { Valeyrie-Allanore, Laurence; Hôpital H Mondor, Dermatology } \\
\text { Ortonne, Nicolas; Hôpital H Mondor, Pathology } \\
\text { Stathopoulos, Efstathios; University of Crete, Pathology } \\
\text { Bagot, Martine; INSERM, U976 } \\
\text { Bensussan, Armand; INSERM, U976 } \\
\text { Mockenhaupt, Maja; Universitäts-Hautklinik } \\
\text { Roujeau, Jean-Claude; Hôpital H Mondor, Dermatology }\end{array}$ \\
\hline Keywords: & human, apoptosis, cytotoxicity, skin, TNF superfamily \\
\hline
\end{tabular}

\section{$\$$ Scholarone}


Death ligand TRAIL, secreted by CD1a+ and CD14+ cells in blister fluids, is involved in killing keratinocytes in toxic epidermal necrolysis

Elisabeth de Araujo ${ }^{1,2}$, Valérie Dessirier ${ }^{1,2}$, Geneviève Laprée ${ }^{2}$, Laurence ValeyrieAllanore $^{3,4,5}$, Nicolas Ortonne ${ }^{6}$, Efstathios N. Stathopoulos ${ }^{7}$, Martine Bagot ${ }^{1,2,9}$, Armand Bensussan $^{1,2,5}$, Maja Mockenhaupt ${ }^{5,8}$, Jean-Claude Roujeau ${ }^{2,3,4,5}$, Andreas Tsapis ${ }^{1,2, *}$

(1) Inserm, U976, Paris, F-75010 France ; Univ Paris-Diderot, Paris, F-75013 France

(2) Inserm, U841, Créteil, F-94010 France ; Univ Paris 12, Créteil, F-94010 France

(3) Dermatology Department, Hôpital Henri Mondor, 94010 Créteil, France

(4) Reference Center on Toxic and Auto-Immune Blistering Diseases, Ile de France, Hôpital Henri Mondor 94010 Créteil, France

(5) RegiSCAR study group

(6) Department of Pathology, Hôpital Henri Mondor, 94010 Créteil, France

(7) Department of Pathology, University of Crete, School of Medicine, Heraklion, Greece

(8) Dokumentationszentrum schwerer Hautreaktionen (dZh), University Medical Center, 79104 Freiburg, Germany

(9) Dermatology Department, Hôpital Saint Louis, 75010 Paris, France

(*) Corresponding author: Dr Andreas TSAPIS, Inserm U976, Equerre Bazin, Hôpital Saint Louis, 1 avenue Claude Vellefaux, 75475 Paris Cedex 10, France. Phone number: +331 53722064, Fax number: +33 1 53722051, E-mail: andreas.tsapis@inserm.fr

Running Title: TRAIL in toxic epidermal necrolysis

Keywords: human, apoptosis, cytotoxicity, skin, TNFSF superfamily

J-C R and A T contributed equally to this paper

28 pages, 4 figures, 2 tables 


\begin{abstract}
\end{abstract}
Toxic epidermal necrolysis (TEN) is characterized by an acute detachment and destruction of keratinocytes, affecting large areas of the skin. It is often related to adverse drug reactions. Previous studies have shown that effector CD8+ T cells, which accumulate in the blister fluid, are functionally cytotoxic and act through a classical perforin/granzyme B pathway. It has recently been shown that these cytotoxic $\mathrm{T}$ cells also secrete granulysin peptide, which is lethal to keratinocytes. These cytotoxic T cells exert their killer activity against autologous keratinocytes in the presence of the drug. However, they are unlikely to be the only effectors of toxic epidermal necrolysis. We therefore searched for soluble death factors in the blister fluids that might kill keratinocytes. We found that the amounts of interferon- $\gamma$, TRAIL, and TNF- $\alpha$ proteins were significantly greater in TEN blister fluids than in all controls (normal sera, TEN sera, burns and Eosinophilic pustular folliculitis blister fluids) and TNF-like weak inducer of apoptosis (TWEAK) amounts are also greater in all controls except burns. We showed that these proteins acted in synergy to induce the death of keratinocytes in vitro. We also found that TRAIL and TWEAK were secreted by CD1a+ and CD14+ cells present in the blister fluids. Thus, in addition to MHC class I-restricted CTLs, which lyse keratinocytes, ligands secreted by non lymphoid cells capable of inducing keratinocyte death in an MHC class I-independent manner, also seem to be present in the blister fluids of patients with toxic epidermal necrolysis. 


\section{Introduction}

The acute detachment and destruction of keratinocytes are hallmark features of two severe adverse skin reactions, toxic epidermal necrolysis (TEN) and Stevens-Johnson syndrome (SJS), affecting large areas of the skin and mucous membranes. This process mostly involves apoptosis $(1,2)$, with some necrosis (3). TEN and SJS differ only in the proportion of the body surface area involved. Patients with epidermal detachment involving $<10 \%$ of body surface area are classified as having SJS, whereas patients with $>30 \%$ of body surface area affected are classified as having TEN. Cases with involvement of between 10 and $30 \%$ of the body surface area are classified as overlap SJS-TEN. Both disorders are frequently related to adverse drug reactions, but may occasionally occur after infection or in association with acute graft-versus-host disease. Both are associated with high morbidity and mortality rates and an unpredictable outcome. Furthermore, clinical diagnosis becomes possible only once the destruction of epithelial cells is already underway $(4,5)$. Elucidating the mechanisms involved in the final pathways of apoptosis should therefore be considered a priority, to provide potential targets for treatments aiming to blocking the reaction, thereby improving the prognosis of these diseases.

In the first few days of SJS or TEN, fluid may accumulate for a few hours under the detached epidermis before the necrotic roof of the blister is breached. Mononuclear cells are present at a relatively high concentration within this blister fluid (6). These "blister fluid cells" comprise variable proportions of lymphocytes and monocytes/macrophages (7).

Lymphocytes from blister fluids have been characterized as activated memory CD8+ T cells, exerting functionally cytotoxic effects through a classical perforin/granzyme B pathway (7, 
8). In four patients from a series of six patients with epidermal necrolysis, the toxicity of these blister fluid cells was found to be specific for the drug molecule suspected of inducing the reaction (9). Without re-stimulation, blister fluid cells killed autologous lymphocytes in the presence of the suspected drug. Similar drug-specific cytotoxicity was also observed against autologous keratinocytes, but only in the presence of interferon- $\gamma$ (IFN- $\gamma$ ) (9). A recent study has shown that granulysin, which is lethal to keratinocytes, is also secreted by the CD8+ cytotoxic cells and NK cells present in the blister fluids (10). The authors showed that secreted granulysin can kill disseminated keratinocytes in SJS and TEN and demonstrated a mechanism for CTL- or NK cell-mediated cytotoxicity that does not require direct cellular contact.

These drug-specific cytotoxic T cells are unlikely to be the only effectors of epidermal necrolysis (11). First, only a moderate T-cell infiltrate is present in the lesions $(12,13)$. Second, similar drug-specific cytotoxic $\mathrm{T}$ cells have also been found in milder drug-related eruptions with no necrolysis (14).

The effects of drug-specific $\mathrm{T}$ cells alone cannot account for the massive destruction of epidermal cells. Indeed, cytokines activating death receptors, such as TNF- $\alpha$ (15-17) and Fas ligand $(2,18)$, may play a key role in amplifying these effects, leading to epidermal necrolysis. In this study, we searched for other soluble death factors produced locally and capable of killing keratinocytes. We identified several "death ligand" proteins and the cells producing these factors, in blister fluids. 


\section{MATERIALS AND METHODS}

\section{Patients}

All patients included in this study were previously included in the European RegiSCAR study of SJS-TEN. All gave written informed consent for samples of blister fluid cells and/or peripheral blood lymphocytes (PBLs) to be taken and used for in vitro analyses, including the use of DNA and RNA. The study was approved by an ethics committee from each participating country. Biological samples were stored in a professional biological resource center. The diagnosis of SJS or TEN was checked by an international group of experts, based on anonymized clinical data, clinical pictures and skin biopsies.

\section{Measurement of TNF- $\alpha$, lymphotoxin $\alpha$, TRAIL, TWEAK, IFN- $\alpha$, FasL and IFN- $\gamma$ levels in blister fluids}

Proteins of interest were determined, by ELISA, in the blister fluids from patients with TEN and in control sera from healthy patients, TEN patients, and blister fluids from burns or EPF patients, with the appropriate kits (Bender MedSystems, Vienna, Austria for TWEAK, IFN- $\alpha$, lymphotoxin- $\alpha$; FasL or Diaclone, Besançon, France for TRAIL, IFN- $\gamma$ and TNF- $\alpha$ ).

\section{Recombinant soluble cytokines, normal human keratinocytes and cell lines}

We used recombinant soluble TWEAK, TRAIL (Alexis, Lausanne, Switzerland) and IFN$\gamma$ (Bender Medsystems) throughout our study. 
$\mathrm{HaCaT}$ is a spontaneously immortalized human keratinocyte cell line (19). Cells were maintained at $37^{\circ} \mathrm{C}$ in 96 -well plates (5000 cells/well) ,in RPMI supplemented with $10 \%$ FCS, and were incubated for $24 \mathrm{~h}$ in an atmosphere containing $5 \% \mathrm{CO}_{2} / 95 \%$ air. Human recombinant cytokines were then added to the medium at the concentrations indicated. Normal human keratinocytes (NHKs; Invitrogen) were grown in keratinocyte-SFM medium (Invitrogen) under the conditions recommended by the manufacturer. For viability tests, cells were seeded at a concentration of 2500 cells/well in flat 96-well dishes. All plastic flasks and dishes used were coated either with Coating Matrix (Cascade Biologics, Portland, OR USA) or with rat tail collagen I (Becton Dickinson, Bedford, MA USA).

Cell viability was assessed with the MTT assay (20), with $20 \mu \mathrm{l}$ of a solution of $5 \mathrm{mg} / \mathrm{ml}$ MTT (Sigma-Aldrich, Lyon, France) in PBS added to each well. The cells were incubated for $4 \mathrm{~h}$ at $37^{\circ} \mathrm{C}$, in an atmosphere containing $5 \% \mathrm{CO}_{2} / 95 \%$ air. Following this treatment, we added $100 \mu \mathrm{l}$ of lysis buffer (20\% SDS in dimethylformamide (DMF)/ $\mathrm{H}_{2} \mathrm{O}(1 / 1)$ solution, $\mathrm{pH}$ 4.7) per well and incubated the cells overnight at $37^{\circ} \mathrm{C}$. The next day we measured the optical density (OD) at $595 \mathrm{~nm}$. Assays were performed in triplicate.

HaCaT cells and NHK were treated with EDTA and were gently removed by mild treatment with trypsin. All floating cells were included in the analysis. Apoptosis of the cells was measured by flow cytometry with an Annexin V/ propidium iodide kit from Bender MedSystems, in a Beckmann-Coulter Epics XL cytometer. Results were analyzed with the WinMDI 2.9 program (http://facs.scripps.edu/software.html). All experiments (viability or apoptosis) were repeated at least once and gave similar results. 


\section{Flow cytometry}

Blister fluid cells were incubated for 30 min in PBS with $10 \%$ human AB serum and then with fluorescent labeled monoclonal antibodies (CD19, CD3, CD4, CD8, CD1a, CD14, CD56 and CD207; from Beckman-Coulter, France), at the dilutions indicated by the manufacturer. Apoptotic and dead cells were stained with 7 aminoactinomycin D (7-AAD) (Sigma-Aldrich, France). Labeled cells were analyzed with a Beckman-Coulter Cytomics FC 500 cytometer.

\section{Immunofluorescence}

Blister cells were immobilized on glass slides by cytospin centrifugation and fixed in acetone. Cells were rehydrated in PBS containing 1\% BSA and $0.05 \%$ saponin and incubated for one hour with appropriate primary antibodies. Cells were then washed three times in the same buffer and incubated for $30 \mathrm{~min}$ with the labeled anti-Ig antibodies. They were then washed again three times. Finally, the cells were rinsed with PBS and mounted in a glycerol/PBS solution (Citifluor, London, UK) containing $3 \mu \mathrm{g} / \mathrm{ml}$ DAPI. Controls were stained with irrelevant primary antibodies,followed by the corresponding labeled secondary antibody.

The primary antibodies, polyclonal goat anti-TRAIL (sc-6079), anti-IFN- $\gamma$ (sc-1377), antiTWEAK (sc-12405) and rabbit anti-granulysin (sc-28821) antibodies were purchased from Santa Cruz Biotechnology, Europe. We also used biotinylated monoclonal antibodies against CD14 (clone 8G3, Diaclone, Besançon, France), CD8 (Dako), CD1a (ImmunotechBeckman), CD56 (Novocastra-Menarini), CD163 (Novocastra-Menarini) and granzyme B (Novocastra-Menarini). All primary antibodies were used at a 1/100 dilution for immunofluorescence tests. Texas Red-conjugated donkey anti-goat F(ab') $)_{2}$, Texas Redconjugated donkey anti-rabbit $\mathrm{F}\left(\mathrm{ab}{ }^{\prime}\right)_{2}$, FITC-conjugated donkey anti-mouse $\mathrm{F}\left(\mathrm{ab}^{\prime}\right)_{2}$ (all three 
purchased from Jackson Immunoresearch Europe, Suffolk, UK) or streptavidin FITCconjugated antibody (Beckman-Coulter) were used as secondary antibodies. Photographs of stained cells were obtained with a Carl Zeiss LSM 510 Meta microscope and the AxionVision Rel 4.7 program. For immunocytochemical analyses, primary antibodies against CD8 (1/200) CD1a (1/2 (pre-diluted)), CD56 (1/50), CD163 (1/400) and granzyme B (1/50) were used after antigen retrieval by heating in pH 9 EDTA buffer (CD8, CD56) or $\mathrm{pH} 6$ citrate buffer (CD1a, CD163 and granzyme B). Slides were stained automatically (Nexes, Ventana), with secondary biotinylated antibodies, avidin-peroxidase and diaminobenzidine chromogen.

\section{Statistical analysis}

All statistical tests were performed with $\mathrm{R}$ software ( $\mathrm{R}$ version 2.10.1

http://cran.cict.fr/. Correlations were considered significant when $\mathrm{p}<0.05$. 


\section{RESULTS}

\section{TRAIL, TNF- $\alpha$, TWEAK and IFN- $\gamma$ protein levels increase significantly in theblister}

\section{fluids of SJS/TEN patients}

We used ELISA to measure the concentrations of TRAIL, IFN- $\gamma$, TNF- $\alpha$, IFN- $\alpha$, lymphotoxin- $\alpha$, FasL and TWEAK proteins in the blister fluids of SJS/TEN patients. TRAIL, IFN- $\gamma$, TNF- $\alpha$ and lymphotoxin- $\alpha$ were already known to be cytotoxic or cytostatic to keratinocytes. Normal sera from healthy subjects and SJS/TEN patients and blister fluids from burns and EPF ptients were used as controls. We detected very low levels of IFN- $\alpha$ and traces of lymphotoxin- $\alpha$ and FasL in a few samples of the blister fluids. However, in most samples, IFN- $\alpha$, FasL and lymphotoxin- $\alpha$ were present at concentrations undetectable by this method. The amounts of TRAIL $(n=16)$, IFN- $\gamma(n=24)$, TNF- $\alpha(n=16)$ and TWEAK $(n=25)$ in blister fluids were higher than those in the sera of healthy subjects (TRAIL: $n=9$; IFN- $\gamma$ : $n=11$; TNF- $\alpha: n=5$; TWEAK: $n=11)$, in the sera of patients with acute SJS/TEN ( $n=4)$, in the blister fluids of burns $(n=4)$ and EPF patients $(n=3)$. However, one exception was identified. The mean TWEAK content of SJS/TEN blister fluids was lower of that of the blister fluids of burns patients. Mean and median cytokine levels for all these samples are shown in Table 1. The mean concentrations of TRAIL and TNF- $\alpha$ in SJS/TEN blister fluids were 10 times higher than those in control sera. These data are shown in figure 1, after nonparametric analysis (Mann-Whitney-Wilcoxon) with R software. The P-values of this statistical analysis are presented in Table 2. All these results indicate that the cytokines investigated are present at significantly higher concentrations in blister fluids than in all control sera, with the exception of TWEAK described above. They show that, like TNF- $\alpha$ and IFN- $\gamma$, which have already been shown to be present at high concentrations in blister fluids $(15,16,21)$, the TNF 
ligands TRAIL and TWEAK are also present at high concentrations in the blister fluids of SJS/TEN patients.

\section{Effect of recombinant TRAIL,TWEAK and IFN- $\gamma$ on the proliferation and apoptosis/necrosis of primary human keratinocytes}

We tested the effect of these death factors on primary human keratinocytes. We found that the addition of recombinant TRAIL resulted in a dose- and time-dependent decrease in NHK viability, due to the apoptosis of the cells as it has been shown previously (22). $10 \mathrm{ng} / \mathrm{ml}$ of TRAIL are required to obtain a $30 \% \pm 6 \%$ decrease in viability at 24 hours (figure $2 \mathrm{~A}$ ). The addition of recombinant IFN- $\gamma$ and TWEAK also decreased the viability of normal human keratinocytes (figure 2B). The addition of a combination of IFN- $\gamma$ and TWEAK $(10 \mathrm{ng} / \mathrm{ml}$ each) resulted in an $80 \% \pm 11 \%$ decrease (96 hours) in viability, suggesting a cooperative effect.

Finally, we examined the effects of IFN- $\gamma$ and TWEAK on the apoptosis of NHKs (figure 2C). We found a slightly higher percentage of late apoptotic cells in cultures treated with 10 $\mathrm{ng} / \mathrm{ml}$ of IFN- $\gamma$ and TWEAK for 48 hours than in controls $(9.76 \% \pm 2.3 \%$ control, $23.26 \% \pm 7.24 \%$ IFN- $\gamma, 13.03 \% \pm 6.5 \%$ TWEAK), with no difference in the proportion of early apoptotic cells or in the percentage of living and dead cells. Only $36 \%$ of cells remained alive ( $28 \%$ necrotic, $35 \%$ late apoptotic) after 48 hours of treatment with a combination of IFN- $\gamma$ and TWEAK (10 ng/ml each), highlighting the synergistic effect of IFN- $\gamma$ and TWEAK on human keratinocyte apoptosis. 


\section{Characterization of cells present in blister fluids from SJS/TEN patients}

Cells were isolated from blister fluids by centrifugation and were either analyzed by MayGrünwald-Giemsa staining after cytospin centrifugugation, or stained with fluorescent antibodies and analyzed by flow cytometry to determine the relative percentage of each type of cell.

One representative experiment, showing the results of May-Grünwald-Giemsa staining, is shown in figure $3 \mathrm{~A}$. In addition to the lymphocytes present in the blister fluids, we found abundant neutrophil cells, together with monocytes, macrophages, dendritic cells and eosinophils. We also stained the cells with specific antibodies and demonstrated the presence of CD1a+, CD8+, CD56+, CD163+ cells and cells secreting granzyme B or granulysin (figure 3B). We detected no B lymphocytes (CD20) or keratinocytes (anti-pan keratin antibody) in any of the TEN blister fluid cell preparations studied.

Flow cytometry analyses of fresh cells from three samples of TEN blister fluids showed the presence of CD8+, CD4+, CD1a+, CD14+, and CD56+ cells. Again, we observed no CD19+ cells in any of the three blister fluid samples analyzed (Table 3). In all three samples, CD56+ cells were present in only small amounts (1-6\% of all cells present in blister fluids), whereas other recent studies have reported these cells to account for more than $40 \%$ of the cells present (10). Our results are more consistent with previous analyses of gated lymphocytes from blister fluids (7). We also report, for the first time, the presence of a small percentage of CD1a+ dendritic cells in blister fluids.

TRAIL and TWEAK are secreted by CD1a+ and CD14+ cells present in blister fluids from SJS/TEN patients 
We identified cells in the blister fluids that produced the death ligands. We used double immunofluorescence staining of blister fluid cells immobilized by cytospin centrifugation and fixed in acetone, as described in the Materials and Methods. The results obtained showed that TRAIL and TWEAK were secreted by both CD1a+ cells and CD14+ cells in the blister fluids (figure 4). Most CD8+ cells seemed to secrete IFN- $\gamma$, with only some of these cells producing granulysin. Similar results were obtained for investigations of the blister fluid cells of six patients. We present the most representative photomicrographs here. 


\section{DISCUSSION}

Cell death is common in many skin diseases, such as sunburn, contact dermatitis, lupus erythematosus, lichen planus and many others (23). Toxic epidermal necrolysis, however, is unique in terms of the aggressiveness and extent of destruction of keratinocytes and also in mostly being caused by the adverse effects of medication. Previous studies have established the link between drugs and the apoptosis of keratinocytes, by demonstrating the presence of drug-specific memory cytotoxic T cells within the skin lesions. These cells kill autologous lymphocytes and keratinocytes in a perforin-mediated, HLA class I-restricted pathway $(8,9)$. Similar drug-specific CTLs are also present in much less severe reactions (14). The number of these cells does not seem to be higher in epidermal necrolysis lesions than in mild cutaneous drug eruptions.

Amplification of cell death may therefore be important in TEN. Earlier studies focused on TNF- $\alpha(15,16)$ or FasL(2). Both are often present at high concentrations in the blister fluid and serum of patients with SJS/TEN. However, one study showed that neither factor was produced by the mononuclear cells present in the lesions (21). FasL levels have also been found to be high in both the serum of patients with mild drug rashes and in the serum of patients with epidermal necrolysis (24). Furthermore, in 76 Japanese SJS/TEN patients with complications affecting the surface of the eye, a strong inverse relationship was shown between four FASL SNPs and SJS/TEN (25). However, a recent immunohistochemical study provided evidence for the presence of granzyme B and TNF- $\alpha$, but not FASL, in SJS/TEN samples (26). Another study showed TNF- $\alpha$ to induce cell-cycle arrest, but not the death of keratinocytes (27). Other factors should also therefore be investigated, to determine their precise roles in the pathogenesis of SJS and TEN (28). A recent report found high 
concentrations of granulysin in the blister fluids of SJS/TEN patients (10). The authors concluded that granulysin is a key mediator of keratinocyte death in SJS/TEN.

In this study, we investigated whether soluble molecules known to be death mediators for keratinocytes were present in blister fluid. IFN- $\gamma$ and TRAIL have already been shown to induce the death of keratinocytes $(22,29-33)$. Keratinocyte proliferation has also been reported to decrease following the addition of LTA (34), possibly due to the death of keratinocytes. We therefore tested blister fluids for the presence of lymphotoxin $\alpha$ protein. We also determined the levels of TNF- $\alpha$, which is known to inhibit keratinocyte proliferation (27), and of IFN- $\alpha$, which kills keratinocytes highly efficiently at low concentrations (1-10 ng/ml) (data not shown). We detected no LTA or IFN- $\alpha$ or FasL in SJS/TEN blister fluids tested in this study. However, in addition to IFN- $\gamma$ and TNF- $\alpha$, which are already known to be produced by blister cells, we found, for the first time, that two more ligands of death receptors, TRAIL and TWEAK, were also produced. The presence of these two factors has not previously been investigated in studies of the effector mechanisms involved in TEN. We found higher concentrations of both TRAIL and TWEAK in SJS/TEN blister fluid cells than in controls (healthy and SJS/TEN patient sera and blister fluids from burns or EPF patients). These proteins were present in the SJS/TEN blister fluids at mean concentrations of $5.9 \mathrm{ng} / \mathrm{ml}$ for TRAIL and $697 \mathrm{pg} / \mathrm{ml}$ for TWEAK. We also demonstrated the inhibition of proliferation and induction of death in normal human keratinocytes (NHKs) incubated with recombinant IFN- $\gamma$, TRAIL and TWEAK, alone or in combination.

The concentrations measured by ELISA strongly underestimate the real concentrations of death ligands, due to consumption and degradation of the molecules. Nonetheless, the mean 
concentrations of TRAIL in blister fluids were similar to those found to be effective at killing keratinocytes in vitro.

The rate of cell death resulting from incubation with TRAIL at concentrations as low as 10 $\mathrm{ng} / \mathrm{ml}$ suggests that this ligand may play a major role in vivo. TRAIL is constitutively expressed in NK cells and markedly upregulated by activation in T cells, NK cells and macrophages. It has a well documented role in mediating cytotoxicity against tumors and virus-infected cells (35), but was more recently shown to induce the apoptosis of non transformed cells, including hepatocytes (36). TRAIL has also been shown to kill HaCaT cells and, to a lesser extent, normal human keratinocytes in vitro, in synergy with IFN- $\gamma(22$, 29-32). We report here the presence of TRAIL in the blister fluids of SJS/TEN patients. The high concentrations of TRAIL in all blister fluids suggest that this molecule is probably a mediator of keratinocyte cell death in toxic epidermal necrolysis.

TWEAK was present at lower concentrations than TRAIL in blister fluids. TWEAK is produced principally by monocytes and macrophages after stimulation with IFN- $\gamma$, inducing apoptosis by interacting with a specific receptor, fibroblast growth factor-inducible 14 (Fn14). TWEAK can also promote the cell death by necrosis $(37,38)$ of tumor cell lines. This is the first time that TWEAK has been shown to induce the death of normal human keratinocytes. Although less marked than the effects of TRAIL, the pro-apoptotic effect of TWEAK alone was significant and this molecule acted in synergy with IFN- $\gamma$.

IFN- $\gamma$ also plays a key role. This cytokine, produced by activated $\mathrm{T}$ lymphocytes, activates monocytes and macrophages (39), but also has a direct effect on apoptosis in the human 
HaCaT cell line (33) and in normal human keratinocytes. IFN- $\gamma$ also acts in synergy with TWEAK in the apoptosis/necrosis of keratinocytes.

The cytotoxic effect of drug-specific CTLs has previously been observed only in autologous keratinocytes subjected to prior incubation with IFN- $\gamma$ and the corresponding drug (9). IFN- $\gamma$ was assumed to be necessary for keratinocyte activation, enhancing their expression of HLA class I molecules. IFN- $\gamma$ is also the principal mediator of monocyte/macrophage and dendritic cell activation, which results in the production of the TRAIL and TWEAK found in blister fluids $(38,40,41)$.

The presence of neutrophils in the blister fluids may result from the chemotaxis of these cells, driven by the high concentrations of IL-8 reported previously (42). IL-8 predominantly recruits neutrophils (43), but also recruits monocytes and T lymphocytes (44).

These and previous findings thus allow us to propose the following model for the final effector mechanisms involved in epidermal necrolysis. Drug-specific CTLs secreting large amounts of IFN- $\gamma$ initiate the MHC-restricted lysis of keratinocytes involving perforin and granzyme B. IFN- $\gamma$ promotes the recruitment and activation of macrophages, monocytes and dendritic cells. These cells in turn produce TRAIL, TWEAK and, possibly, other cytokines. Large numbers of keratinocytes are then killed through the cooperative action of these factors with the IFN- $\gamma$ present in blister fluids, through an MHC-independent pathway. Our results clearly demonstrate the production of TRAIL and TWEAK by CD1a+ and CD14+ cells in the blister fluid of SJS/TEN patients. 
Our findings suggest that severe cutaneous adverse reactions, such as SJS/TEN, do not arise due to the action of one factor alone. Indeed, no single factor appears sufficient to explain the complex pathogenesis. Instead, a combination of many factors, some of which have been identified before (perforin, granzyme B, granulysin, IFN- $\gamma$ ), together with TRAIL and TWEAK, may underlie the aggressive epidermal destruction in TEN.

Several questions concerning the pathophysiology of this disease remain unsolved. One recent paper described endothelial cell apoptosis during TEN (26). This new finding is important for determining factors that may worsen skin damage. Its relevance may also extend to other organs, generating additional unanswered questions. In particular, it remains unclear why the epithelial cells of the skin and mucous membranes are the major targets of the reaction and why the reaction is so aggressive in epidermal necrolysis, but not in mild drug eruptions in which drug-specific CTLs are also present in the skin.

Most studies on TEN have characterized the cells and molecules involved in keratinocyte destruction. All the cells and molecules described are the end products of a long process starting several days before the appearance of skin blisters, when the drug is ingested. Several gaps remain in our understanding of the early steps of the immune reaction leading to destructive epidermal necrolysis. Once blisters appear, the phenomenon cannot be reversed. Withdrawal of the drug implicated (45) and early treatment with an immunosuppressant, such as cyclosporin A (46), or human immunoglobulins (2)may halt the progression of epidermal detachment. We need to elucidate the role of each type of cell present in the blister fluid during the progression of epidermal necrolysis, to improve our understanding of this disease. In particular, the role of CD4+ cells in initiating the phenomenon, the role of Treg cells in controlling the response (47) and the role of the dendritic cells and monocytes present in the 
blister fluids should be addressed. A recent study has shown that Treg cells, although present in normal numbers, display strong functional impairment in TEN, with normal function restored on recovery. These findings suggest that a transient impairment of Treg cells function during the acute stage of TEN may be related to severe epidermal damage (48). This pioneering work should be continued, to elucidate the precise mechanisms underlying this impairment, thereby helping to resolve the unanswered questions relating to toxic epidermal necrolysis. 
Acknowledgments

This study was funded by Inserm (Institut National de la Santé et de la Recherche Médicale) and by grants for the RegiSCAR study (European Commission (QLRT-2002-01738), ORPHANET, GIS-Institut des Maladies Rares in France, DFG (FOR 534) in Germany and a consortium of pharmaceutical companies including Bayer Vital, Boehringer-Ingelheim, GlaxoSmithKline, MSD Sharp \& Dohme, Merck, Novartis, Pfizer, Roche, Sanofi-Aventis, Servier).

We thank Mr Niclas Setterblad and Ms Christelle Doliger at the Imaging Department of the Institut Universitaire d'Hématologie (Université Paris Diderot, France) for skillful help with the fluorescence images. The imaging department is supported by grants from the Conseil Regional d'Ile-de-France, the Canceropôle Ile-de-France and the Ministère de la Recherche.

We also thank Ms Juliette Gray and Julie Sappa for careful reading and improvement of the English of this paper. 
References

1. Paul C, Wolkenstein P, Adle H et al. Apoptosis as a mechanism of keratinocyte death in toxic epidermal necrolysis. Br J Dermatol 1996: 134: 710-714.

2. Viard I, Wehrli P, Bullani R et al. Inhibition of toxic epidermal necrolysis by blockade of CD95 with human intravenous immunoglobulin. Science 1998: 282: 490-493.

3. Paquet P,Pierard G E. Toxic epidermal necrolysis: revisiting the tentative link between early apoptosis and late necrosis (review). Int J Mol Med 2007: 19: 3-10.

4. Roujeau J C, Kelly J P, Naldi L et al. Medication use and the risk of Stevens-Johnson syndrome or toxic epidermal necrolysis. N Engl J Med 1995: 333: 1600-1607.

5. Mockenhaupt M, Viboud C, Dunant A et al. Stevens-Johnson syndrome and toxic epidermal necrolysis: assessment of medication risks with emphasis on recently marketed drugs. The EuroSCAR-study. J Invest Dermatol 2008: 128: 35-44.

6. Correia O, Delgado L, Ramos J P, Resende C,Torrinha J A. Cutaneous T-cell recruitment in toxic epidermal necrolysis. Further evidence of CD8+ lymphocyte involvement. Arch Dermatol 1993: 129: 466-468.

7. Le Cleach L, Delaire S, Boumsell L et al. Blister fluid T lymphocytes during toxic epidermal necrolysis are functional cytotoxic cells which express human natural killer (NK) inhibitory receptors. Clin Exp Immunol 2000: 119: 225-230.

8. Nassif A, Bensussan A, Dorothee G et al. Drug specific cytotoxic T-cells in the skin lesions of a patient with toxic epidermal necrolysis. J Invest Dermatol 2002: 118: 728-733.

9. Nassif A, Bensussan A, Boumsell L et al. Toxic epidermal necrolysis: effector cells are drug-specific cytotoxic T cells. J Allergy Clin Immunol 2004: 114: 1209-1215. 
10. Chung W H, Hung S I, Yang J Y et al. Granulysin is a key mediator for disseminated keratinocyte death in Stevens-Johnson syndrome and toxic epidermal necrolysis. Nat Med 2008: 14: 1343-1350.

11. Chave T A, Mortimer N J, Sladden M J, Hall A P,Hutchinson P E. Toxic epidermal necrolysis: current evidence, practical management and future directions. Br J Dermatol 2005: 153: 241-253.

12. Miyauchi H, Hosokawa H, Akaeda T, Iba H,Asada Y. T-cell subsets in drug-induced toxic epidermal necrolysis. Possible pathogenic mechanism induced by CD8-positive T cells. Arch Dermatol 1991: 127: 851-855.

13. Villada G, Roujeau J C, Clerici T, Bourgault I,Revuz J. Immunopathology of toxic epidermal necrolysis. Keratinocytes, HLA-DR expression, Langerhans cells, and mononuclear cells: an immunopathologic study of five cases. Arch Dermatol 1992: 128: $50-53$.

14. Schnyder B, Burkhart C, Schnyder-Frutig K et al. Recognition of sulfamethoxazole and its reactive metabolites by drug-specific CD4+ T cells from allergic individuals. $\mathrm{J}$ Immunol 2000: 164: 6647-6654.

15. Paquet P, Nikkels A, Arrese J E, Vanderkelen A,Pierard G E. Macrophages and tumor necrosis factor alpha in toxic epidermal necrolysis. Arch Dermatol 1994: 130: 605608.

16. Paquet P,Pierard G E. Soluble fractions of tumor necrosis factor-alpha, interleukin-6 and of their receptors in toxic epidermal necrolysis: a comparison with second-degree burns. Int J Mol Med 1998: 1: 459-462.

17. Wolkenstein P, Latarjet J, Roujeau J C et al. Randomised comparison of thalidomide versus placebo in toxic epidermal necrolysis. Lancet 1998: 352: 1586-1589.

18. Abe R, Shimizu T, Shibaki A, Nakamura H, Watanabe H,Shimizu H. Toxic epidermal necrolysis and Stevens-Johnson syndrome are induced by soluble Fas ligand. Am J Pathol 2003: 162: 1515-1520. 
19. Boukamp P, Petrussevska R T, Breitkreutz D, Hornung J, Markham A,Fusenig N E. Normal keratinization in a spontaneously immortalized aneuploid human keratinocyte cell line. J Cell Biol 1988: 106: 761-771.

20. Hansen M B, Nielsen S E,Berg K. Re-examination and further development of a precise and rapid dye method for measuring cell growth/cell kill. J Immunol Methods 1989: 119: 203-210.

21. Nassif A, Moslehi H, Le Gouvello S et al. Evaluation of the potential role of cytokines in toxic epidermal necrolysis. J Invest Dermatol 2004: 123: 850-855.

22. Leverkus M, Sprick M R, Wachter T et al. TRAIL-induced apoptosis and gene induction in HaCaT keratinocytes: differential contribution of TRAIL receptors 1 and 2. J Invest Dermatol 2003: 121: 149-155.

23. Raj D, Brash D E,Grossman D. Keratinocyte apoptosis in epidermal development and disease. J Invest Dermatol 2006: 126: 243-257.

24. Stur K, Karlhofer F M,Stingl G. Soluble FAS ligand: a discriminating feature between drug-induced skin eruptions and viral exanthemas. J Invest Dermatol 2007: 127: 802807.

25. Ueta M, Sotozono C, Inatomi T, Kojima K, Hamuro J,Kinoshita S. Association of Fas Ligand gene polymorphism with Stevens-Johnson syndrome. Br J Ophthalmol 2008: 92: 989-991.

26. Verneuil L, Ratajczak P, Allabert C et al. Endothelial cell apoptosis in severe druginduced bullous eruptions. Br J Dermatol 2009: 161: 1371-1375.

27. Banno T, Gazel A,Blumenberg M. Effects of tumor necrosis factor-alpha (TNF alpha) in epidermal keratinocytes revealed using global transcriptional profiling. J Biol Chem 2004: 279: 32633-32642.

28. Murata J,Abe R. Soluble Fas ligand: is it a critical mediator of toxic epidermal necrolysis and Stevens-Johnson syndrome? J Invest Dermatol 2007: 127: 744-745. 
29. Leverkus M, Neumann M, Mengling T et al. Regulation of tumor necrosis factor-related apoptosis-inducing ligand sensitivity in primary and transformed human keratinocytes. Cancer Res 2000: 60: 553-559.

30. Qin J Z, Bacon P, Chaturvedi V,Nickoloff B J. Role of NF-kappaB activity in apoptotic response of keratinocytes mediated by interferon-gamma, tumor necrosis factor-alpha, and tumor-necrosis-factor-related apoptosis-inducing ligand. J Invest Dermatol 2001: 117: 898-907.

31. Wachter T, Sprick M, Hausmann D et al. cFLIPL inhibits tumor necrosis factor-related apoptosis-inducing ligand-mediated NF-kappaB activation at the death-inducing signaling complex in human keratinocytes. J Biol Chem 2004: 279: 52824-52834.

32. Chaturvedi V, Bodner B, Qin J Z,Nickoloff B J. Knock down of p53 levels in human keratinocytes increases susceptibility to type I and type II interferon-induced apoptosis mediated by a TRAIL dependent pathway. J Dermatol Sci 2006: 41: 31-41.

33. Konur A, Schulz U, Eissner G, Andreesen R,Holler E. Interferon (IFN)-gamma is a main mediator of keratinocyte (HaCaT) apoptosis and contributes to autocrine IFN-gamma and tumour necrosis factor-alpha production. Br J Dermatol 2005: 152: 1134-1142.

34. Symington F W. Lymphotoxin, tumor necrosis factor, and gamma interferon are cytostatic for normal human keratinocytes. J Invest Dermatol 1989: 92: 798-805.

35. Smyth M J, Cretney E, Takeda K et al. Tumor necrosis factor-related apoptosis-inducing ligand (TRAIL) contributes to interferon gamma-dependent natural killer cell protection from tumor metastasis. J Exp Med 2001: 193: 661-670.

36. Jo M, Kim T H, Seol D W et al. Apoptosis induced in normal human hepatocytes by tumor necrosis factor-related apoptosis-inducing ligand. Nat Med 2000: 6: 564-567.

37. Wilson C A,Browning J L. Death of HT29 adenocarcinoma cells induced by TNF family receptor activation is caspase-independent and displays features of both apoptosis and necrosis. Cell Death Differ 2002: 9: 1321-1333.

38. Nakayama M, Ishidoh K, Kojima Y et al. Fibroblast growth factor-inducible 14 mediates multiple pathways of TWEAK-induced cell death. J Immunol 2003: 170: 341-348. 
39. Nathan C F, Murray H W, Wiebe M E,Rubin B Y. Identification of interferon-gamma as the lymphokine that activates human macrophage oxidative metabolism and antimicrobial activity. J Exp Med 1983: 158: 670-689.

40. Griffith T S, Wiley S R, Kubin M Z, Sedger L M, Maliszewski C R,Fanger N A. Monocyte-mediated tumoricidal activity via the tumor necrosis factor-related cytokine, TRAIL. J Exp Med 1999: 189: 1343-1354.

41. Fanger N A, Maliszewski C R, Schooley K,Griffith T S. Human dendritic cells mediate cellular apoptosis via tumor necrosis factor-related apoptosis-inducing ligand (TRAIL). J Exp Med 1999: 190: 1155-1164.

42. Paquet P, Ribbens C,Pierard G E. Epidermal interleukin-8 and its receptor CXCR2 in drug-induced toxic epidermal necrolysis. Clin Exp Dermatol 2007: 32: 728-732.

43. Schmidt E, Ambach A, Bastian B, Brocker E B,Zillikens D. Elevated levels of interleukin-8 in blister fluid of bullous pemphigoid compared with suction blisters of healthy control subjects. J Am Acad Dermatol 1996: 34: 310-312.

44. Santamaria Babi L F, Moser B, Perez Soler M T et al. The interleukin-8 receptor B and CXC chemokines can mediate transendothelial migration of human skin homing $\mathrm{T}$ cells. Eur J Immunol 1996: 26: 2056-2061.

45. Garcia-Doval I, LeCleach L, Bocquet H, Otero X L,Roujeau J C. Toxic epidermal necrolysis and Stevens-Johnson syndrome: does early withdrawal of causative drugs decrease the risk of death? Arch Dermatol 2000: 136: 323-327.

46. Paquet P,Pierard G E. Would cyclosporin A be beneficial to mitigate drug-induced toxic epidermal necrolysis? Dermatology 1999: 198: 198-202.

47. Mizukawa Y, Yamazaki Y,Shiohara T. In vivo dynamics of intraepidermal CD8+ T cells and CD4+ T cells during the evolution of fixed drug eruption. Br J Dermatol 2008: 158: $1230-1238$.

48. Takahashi R, Kano Y, Yamazaki Y, Kimishima M, Mizukawa Y,Shiohara T. Defective regulatory $\mathrm{T}$ cells in patients with severe drug eruptions: timing of the dysfunction is 
associated with the pathological phenotype and outcome. J Immunol 2009: 182: 80718079. 


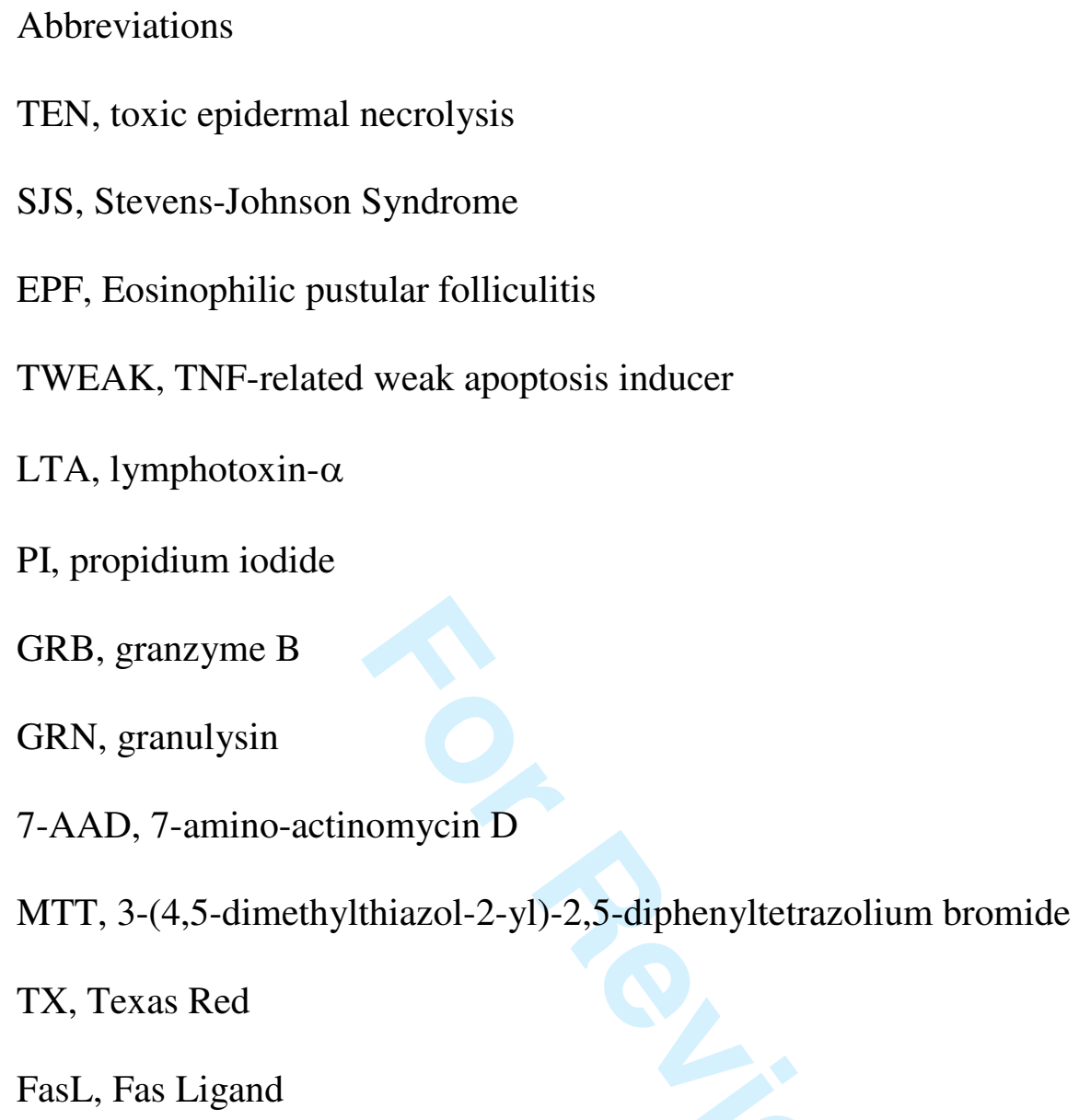


Figure legends

Figure 1. Analyses of cytotoxic proteins in the blister fluids. Amounts of TRAIL, TNF- $\alpha$, IFN- $\gamma$ and TWEAK in the blister fluid (BF) of subjects with SJS/TEN, in the serum of healthy subjects (NHS), in the serum of Lyell (SJS/TEN) patients (SL), in blister fluids of burns patients (BU) and in blister fluids of EPF patients (EPF), as measured by ELISA. We investigated the correlation between cytotoxic protein levels in blister fluids of SJS/TEN patients and cytotoxic protein levels in the serum of controls by non parametric analysis (Man-Whitney-Wilcoxon), using the R statistical program. The P values obtained are shown (* $\mathrm{P}<0.05, * * \mathrm{P}<0.005, * * * \mathrm{P}<0.0005)$. The horizontal lines indicate the median values obtained.

Figure 2. Viability of normal human keratinocytes in the presence of various amounts of TRAIL alone (A), in the presence of $10 \mathrm{ng} / \mathrm{ml}$ TWEAK or $10 \mathrm{ng} / \mathrm{ml} \mathrm{IFN}-\gamma$, and in the presence of $10 \mathrm{ng} / \mathrm{ml}$ IFN- $\gamma$ plus $10 \mathrm{ng} / \mathrm{ml}$ TWEAK (B). Apoptotic NHKs (C) (stained with AnnexinV-FITC and PI) after 48 hours of incubation in the presence of medium, $10 \mathrm{ng} / \mathrm{ml}$ IFN- $\gamma, 10 \mathrm{ng} / \mathrm{ml}$ TWEAK and $10 \mathrm{ng} / \mathrm{ml}$ each of IFN- $\gamma$ plus TWEAK. UL dead cells, UR late apoptotic cells, LL living cells and LR early apoptotic cells.

Figure 3. (A) May-Grünwald-Giemsa staining of blister fluid cells. Arrows indicate characteristic cells of the blister fluid. D dendritic cell, N neutrophil, E eosinophil, L lymphocyte, MФ macrophage, Mo monocyte and R red blood cell. Bar $20 \mu \mathrm{m}$. (B) Blister fluid cells were stained with antibodies against CD1a, CD8, CD56, CD163, granzyme B (GRB) and granulysin (GRN), as described in Materials and Methods. 
Figure 4. Immunofluorescence staining of blister fluid cells with mAb against CD1a, CD14 and CD8 immunotypes (FITC). Cells were also stained with goat polyclonal antibodies against TRAIL, TWEAK, IFN- $\gamma$ or granulysin (Texas Red, TX). Bar $20 \mu \mathrm{m}$. (A) CD1a+(FITC), TWEAK+ (TX); (B) CD1a+ (FITC), TRAIL+ (TX); (C) CD14+ (FITC), TWEAK+ (TX); (D) CD14+ (FITC), TRAIL+ (TX); (E) CD8+ (FITC), IFN- $\gamma+($ TX); (F) CD8+ (FITC), granulysin+ (TX). 
TRAIL

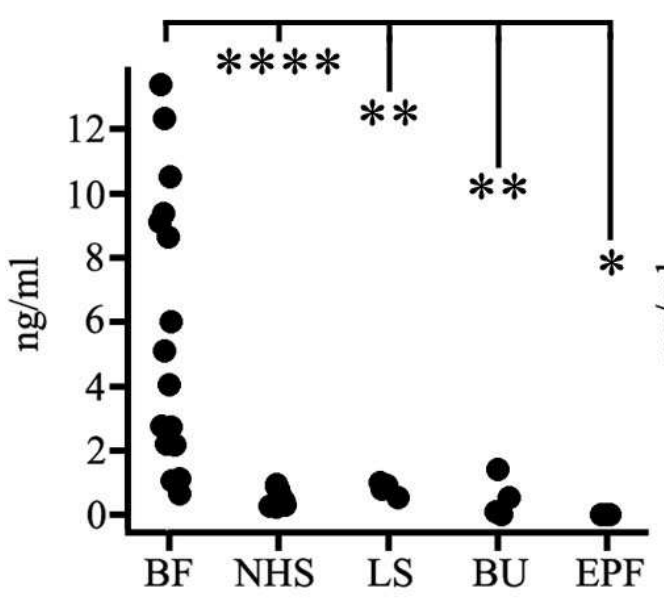

IFN- $\gamma$

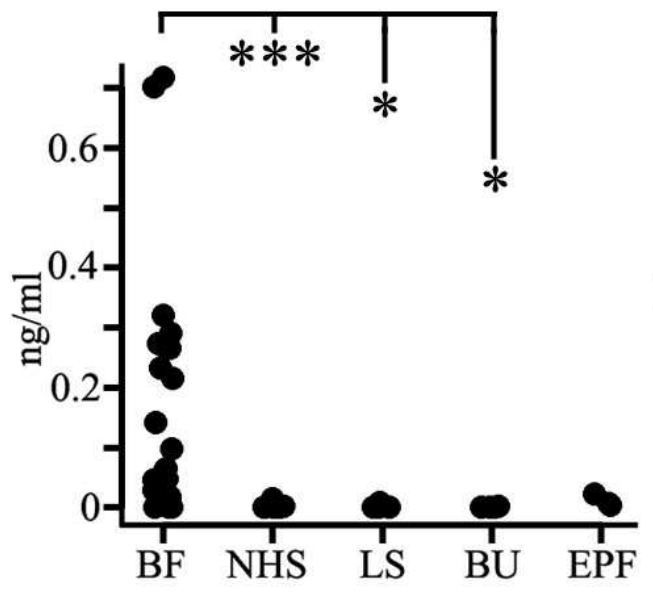

TNF- $\alpha$

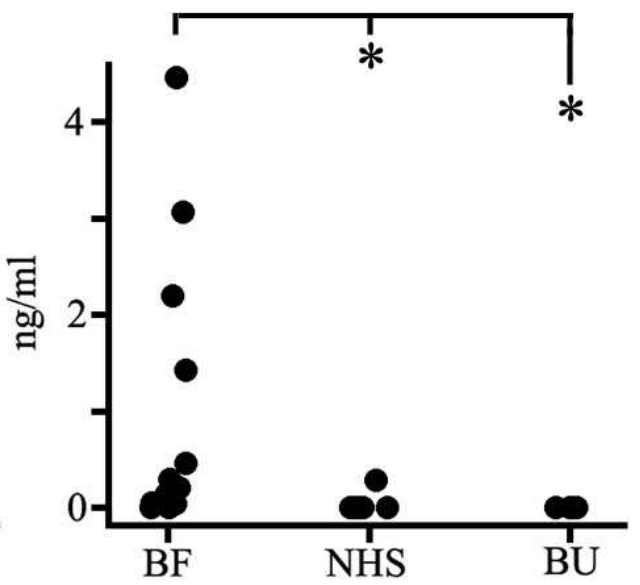

TWEAK

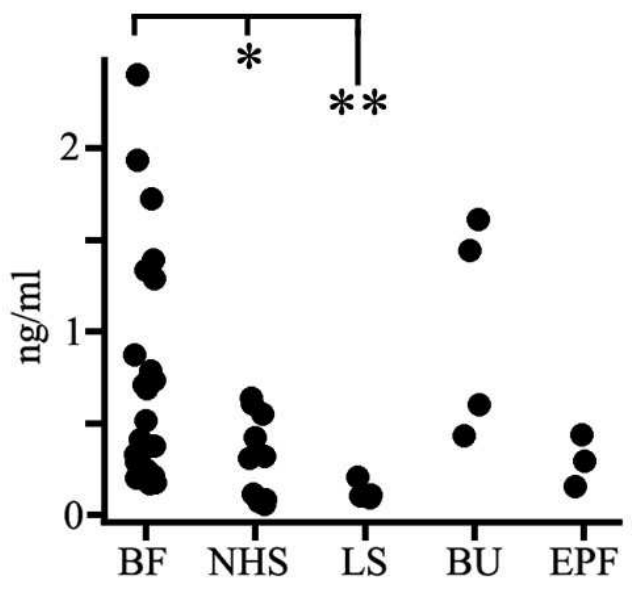

Figure 1. Analyses of cytotoxic proteins in the blister fluids. Amounts of TRAIL, TNF- , IFN- and TWEAK in the blister fluid (BF) of subjects with SJS/TEN, in the serum of healthy subjects (NHS), in the serum of Lyell (SJS/TEN) patients (SL), in blister fluids of burns patients (BU) and in blister fluids of EPF patients (EPF), as measured by ELISA. We investigated the correlation between cytotoxic protein levels in blister fluids of SJS/TEN patients and cytotoxic protein levels in the serum of controls by non parametric analysis (Man-Whitney-Wilcoxon), using the R statistical program. The $\mathrm{P}$ values obtained are shown ( $* \mathrm{P}<0.05, * * \mathrm{P}<0.005, * * * \mathrm{P}<0.0005)$. The horizontal lines indicate the median values obtained. $83 \times 94 \mathrm{~mm}(300 \times 300 \mathrm{DPI})$ 

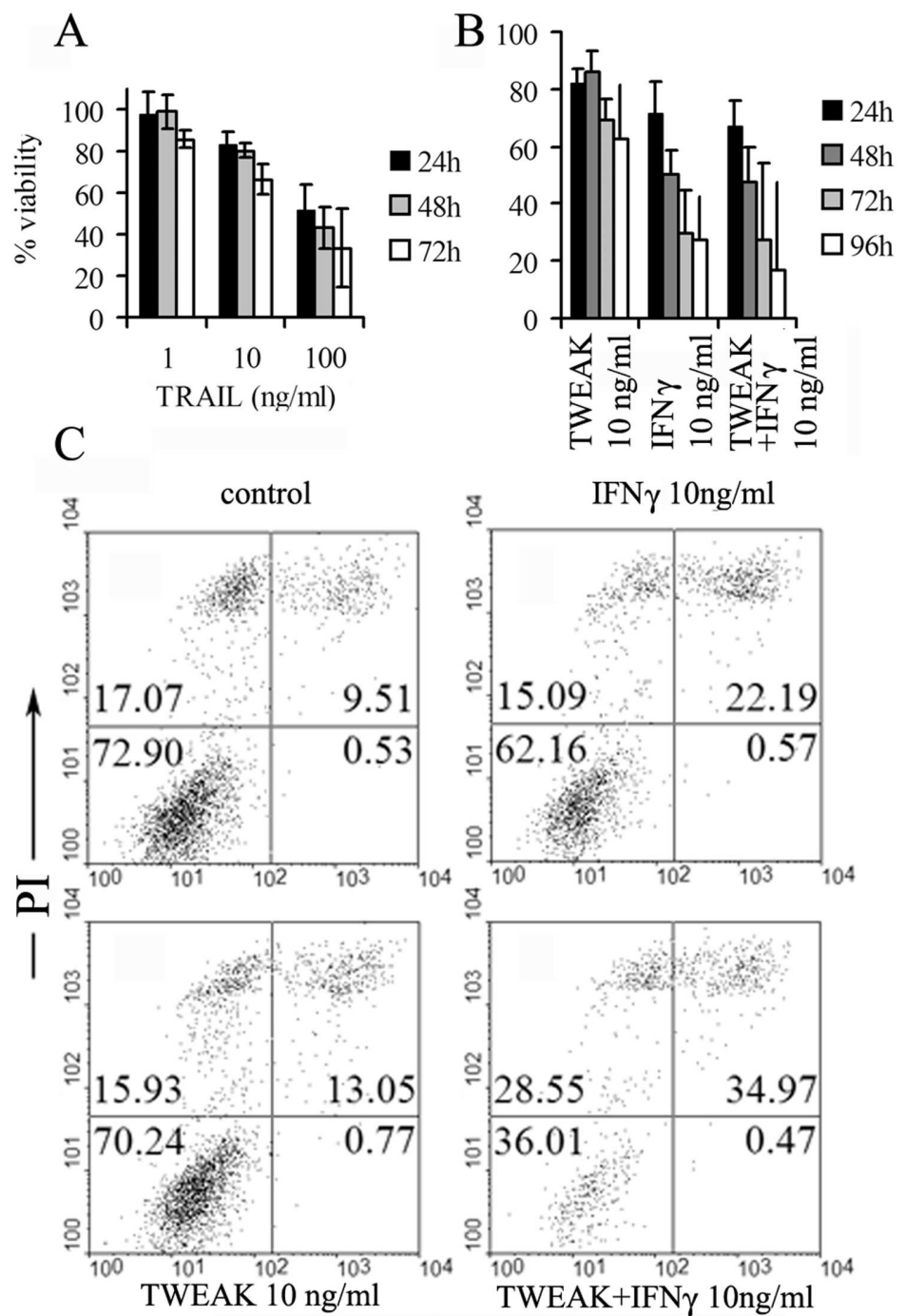

AnnexinV-FITC

Fig 2

Figure 2. Viability of normal human keratinocytes in the presence of various amounts of TRAIL alone (A), in the presence of $10 \mathrm{ng} / \mathrm{ml} \mathrm{TWEAK} \mathrm{or} 10 \mathrm{ng} / \mathrm{ml} \mathrm{IFN-} \mathrm{,} \mathrm{and} \mathrm{in} \mathrm{the} \mathrm{presence} \mathrm{of} 10 \mathrm{ng} / \mathrm{ml}$ IFNplus $10 \mathrm{ng} / \mathrm{ml}$ TWEAK (B). Apoptotic NHKs (C) (stained with AnnexinV-FITC and PI) after 48 hours of incubation in the presence of medium, $10 \mathrm{ng} / \mathrm{ml}$ IFN- , $10 \mathrm{ng} / \mathrm{ml}$ TWEAK and $10 \mathrm{ng} / \mathrm{ml}$ each of IFN- . plus TWEAK. UL dead cells, UR late apoptotic cells, LL living cells and LR early apoptotic cells. $130 \times 211 \mathrm{~mm}(600 \times 600 \mathrm{DPI})$ 
Figure 3. (A) May-Grünwald-Giemsa staining of blister fluid cells. Arrows indicate characteristic cells of the blister fluid. D dendritic cell, N neutrophil, E eosinophil, L lymphocyte, M . macrophage, Mo monocyte and R red blood cell. Bar $20 \mu \mathrm{m}$. (B) Blister fluid cells were stained with antibodies against CD1a, CD8, CD56, CD163, granzyme B (GRB) and granulysin (GRN), as described in Materials and Methods. $82 \times 160 \mathrm{~mm}(300 \times 300 \mathrm{DPI})$ 


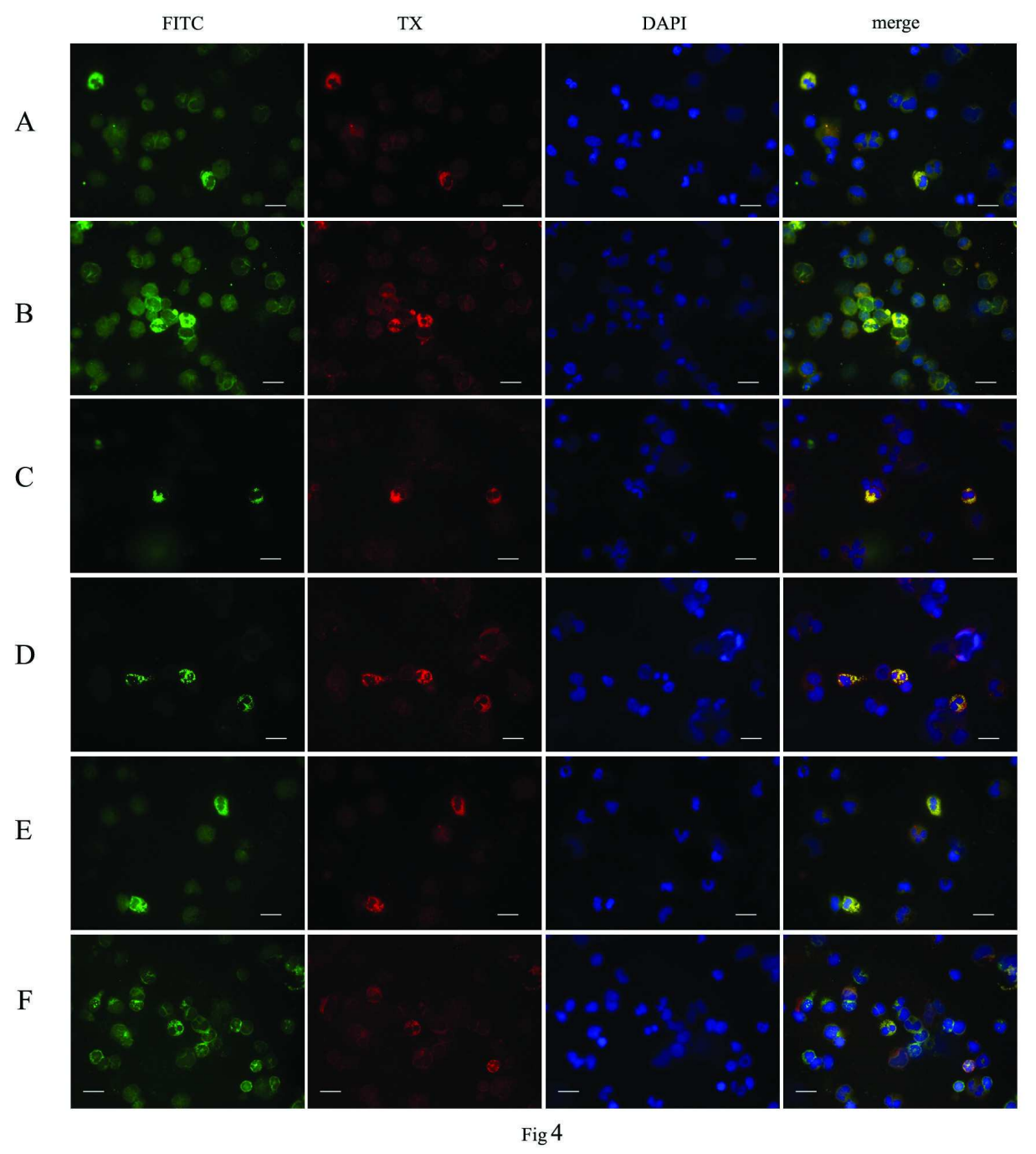

Figure 4. Immunofluorescence staining of blister fluid cells with mAb against CD1a, CD14 and CD8 immunotypes (FITC). Cells were also stained with goat polyclonal antibodies against TRAIL, TWEAK, IFN- or granulysin (Texas Red, TX). Bar $20 \mu \mathrm{m}$. (A) CD1a+(FITC), TWEAK+ (TX); (B) CD1a+ (FITC), TRAIL+ (TX); (C) CD14+ (FITC), TWEAK+ (TX); (D) CD14+ (FITC), TRAIL+ (TX); (E) CD8+ (FITC), IFN- + (TX); (F) CD8+ (FITC), granulysin+ (TX). $160 \times 170 \mathrm{~mm}(300 \times 300 \mathrm{DPI})$ 
Table 1A. Estimation, by ELISA, of the quantity of TRAIL, TNF- $\alpha$, IFN- $\gamma$, and TWEAK

\begin{tabular}{|l|c|c|c|c|}
\hline & TRAIL pg/ml & TNF- $\alpha$ pg/ml & IFN- $\gamma$ pg/ml & TWEAK pg/ml \\
\hline $\begin{array}{l}\text { SJS/TEN } \\
\text { blister } \\
\text { fluids }\end{array}$ & $\begin{array}{c}5,968.4 \pm 4,269.8 \\
\text { median=4,565 }\end{array}$ & $\begin{array}{c}795.3 \pm 1,329.9 \\
\text { median=154.5 }\end{array}$ & $\begin{array}{c}174 \pm 198.9 \\
\text { median=81.5 }\end{array}$ & $\begin{array}{c}697.8 \pm 603.3 \\
\text { median=412 }\end{array}$ \\
\hline $\begin{array}{l}\text { Normal } \\
\text { human } \\
\text { serum }\end{array}$ & $\begin{array}{c}535 \pm 283 \\
\text { median=409 }\end{array}$ & $\begin{array}{c}57.05 \pm 126.8 \\
\text { median=0 }\end{array}$ & $\begin{array}{c}1.8 \pm 4.1 \\
\text { median=0.2 }\end{array}$ & $\begin{array}{c}294.4 \pm 229.2 \\
\text { median=310 }\end{array}$ \\
\hline $\begin{array}{l}\text { SJS/TEN } \\
\text { patients } \\
\text { sera }\end{array}$ & $\begin{array}{c}818 \pm 203 \\
\text { median=860 }\end{array}$ & ND & $\begin{array}{c}2.25 \pm 4.5 \\
\text { median=0 }\end{array}$ & $\begin{array}{c}127 \pm 53 \\
\text { median=105.5 }\end{array}$ \\
\hline $\begin{array}{l}\text { Burns } \\
\text { patients }\end{array}$ & $\begin{array}{c}548 \pm 606 \\
\text { median=316.5 }\end{array}$ & $\begin{array}{c}0.75 \pm 1.5 \\
\text { median=0 }\end{array}$ & $\begin{array}{c}1 \pm 0.8 \\
\text { median=1 }\end{array}$ & $\begin{array}{c}1020 \pm 592 \\
\text { median=1019.5 }\end{array}$ \\
\hline $\begin{array}{l}\text { EPF } \\
\text { patients }\end{array}$ & $\begin{array}{c}11 \pm 11 \\
\text { median=0 }\end{array}$ & ND & $\begin{array}{c}11 \pm 11 \\
\text { median=6 }\end{array}$ & median=291 \\
\hline
\end{tabular}

Table 1B. Estimation of p-values

\begin{tabular}{|l|c|c|c|c|}
\cline { 2 - 5 } \multicolumn{1}{c|}{} & \multicolumn{4}{c|}{ p-values } \\
\cline { 2 - 5 } \multicolumn{1}{c|}{} & TRAIL & TNF- $\alpha$ & IFN- $\gamma$ & TWEAK \\
\hline BF/NHS & 0.000006358 & 0.03125 & 0.0001008 & 0.02475 \\
\hline BF/LS & 0.002890 & ND & 0.00767 & 0.0007628 \\
\hline BF/BU & 0.002890 & 0.007913 & 0.01139 & 0.1927 \\
\hline BF/EPF & 0.008488 & ND & 0.064 & 0.2532 \\
\hline NHS/LS & 0.1483 & ND & 0.5711 & 0.5714 \\
\hline NHS/BU & 0.6042 & 0.771 & 0.6847 & 0.02637 \\
\hline NHS/EPF & 0.01549 & ND & 0.02579 & 0.8846 \\
\hline
\end{tabular}

Significative value when $\mathrm{p}<0.05$,

$\mathrm{BF}=\mathrm{SJS} / \mathrm{TEN}$ blister fluids, NHS= normal human serum, $\mathrm{LS}=\mathrm{SJS} / \mathrm{TEN}$ serum, $\mathrm{BU}=\mathrm{Burns}$ ' blister fluids, $\mathrm{EPF}=$ Eosinophilic pustular folliculitis blister fluids. 
Table 2. Immunophenotypes of blister cells from patients with Stevens-Johnson syndrome/toxic epidermal necrolysis

\begin{tabular}{|l|l|l|l|}
\hline & Case 1 & Case 2 & Case 3 \\
\hline CD1a+ & $1.59 \%$ & $4.33 \%$ & $0.41 \%$ \\
\hline CD3+ lymphocytes & $45.86 \%$ & $3.37 \%$ & $22.87 \%$ \\
\hline CD4+ lymphocytes & $10.58 \%$ & $4.92 \%$ & $4.55 \%$ \\
\hline CD8+ lymphocytes & $36.17 \%$ & $1.09 \%$ & $15.61 \%$ \\
\hline CD14+ & $18.62 \%$ & $31.32 \%$ & $1.35 \%$ \\
\hline CD56+ & $4.63 \%$ & $0.37 \%$ & $3.03 \%$ \\
\hline CD207+ & $0.08 \%$ & $0.14 \%$ & $4.43 \%$ \\
\hline
\end{tabular}

